\title{
Copy Number Variation Analysis in Turkish Patients with Congenital Bilateral Absence of Vas Deferens
}

\author{
Konjenital Bilateral Vas Deferens Yokluğu Olan Türk Hastalarda Genomik Kopya Sayısı \\ Varyasyonları Analizi
}

Durkadin Demir Eksi ${ }^{*}$, Elanur Yilmaz ${ }^{2}$, Yigit Akin ${ }^{3}$, Mustafa Faruk Usta ${ }^{4}$, Mehmet Murad Basar ${ }^{5}$, Semra Kahraman $^{6}$, Munire Erman ${ }^{7}$, Ozgul M Alper ${ }^{8}$

1. Alanya Alaaddin Keykubat University, Faculty of Medicine, Department of Medical Biology, Antalya, Turkey

2. Koç University, Research Center of Translational Medicine İstanbul, Turkey

3. İzmir Katip Çelebi University, Faculty of Medicine, Department of Urology, İzmir, Turkey

4. Akdeniz University, Faculty of Medicine, Department of Urology, Antalya, Turkey

5. Memorial Şişli Hospital, Department of Urology, İstanbul, Turkey

6. Memorial Şişli Hospital, Department of Gynecology and Obstetrics, Istanbul, Turkey

7. Akdeniz University, Faculty of Medicine, Department of Gynecology and Obstetrics, Antalya, Turkey

8. Akdeniz University, Faculty of Medicine, Department of Medical Biology and Genetics, Antalya, Turkey

\section{ABSTRACT}

Objective: Congenital Bilateral Absence of the Vas Deferens (CBAVD) is a developmental abnormality that causes infertility in males. According to the literature, up to $88 \%$ of CBAVD cases have at least one pathogenic Cystic Fibrosis Transmembrane Conductance Regulator gene (CFTR) mutation. However, based on our previous data, this rate was $15.90 \%$ in Turkish patients with CBAVD. We aimed to identify genomic copy number variations (CNV) and candidate genomic regions which could related to the CBAVD in Turkish population.

Methods: CNV analysis was performed in 19 Turkish CBAVD patients normal karyotypes and a wild type CFTR genotype. We suggested that the DAD1 gene may be a candidate gene related to CBAVD by reviewing online databases and analyzing CNV findings. Sanger sequencing of the DAD1 gene exons was performed in 22 patients.

Results: We identified $11 \mathrm{CNVs}$ that most likely related with the disease in nine of 19 (47.3\%) patients. As the most common CNV, 14q11.2 deletions were detected in there $(15.79 \%)$ of the patients. There was only DAD1 gene in the sharing genomic region of two of the $14 q 11.2$ deletions. No sequence variation was detected in the DAD1 gene of the patients.

Conclusion: The $14 \mathrm{q} 11.2$ chromosomal region and the DAD1 gene may be associated with CBAVD. Further studies are needed to indentify the contribution of CNVs and DAD1 gene to CBAVD etiology.

Keywords: copy number variations; CBAVD; male infertility; DAD1

\section{öz}

Amaç: Konjenital Bilateral Vas Deferens Yokluğu (CBAVD), erkeklerde infertiliteye yol açan gelişimsel bir anomalidir. Literatüre göre CBAVD'li olguların \%88'e kadarı en az bir Kistik Fibrozis Transmembran Regülatör geni (CFTR) mutasyonuna sahiptir. Ancak, daha önceki verilerimize göre CBAVD'li Türk hastalarda bu oran \% 15.90 'dır. Çalışmamız kapsamında Türk popülasyonundaki CBAVD ile ilişkili olabilecek genomik kopya sayısı varyasyonları (CNV) ve aday genomik bölgelerin tanımlanmas amaçlanmıştır.

Yöntemler: Normal karyotipe ve yabanıl tip CFTR genotipine sahip 19 Türk CBAVD'll hastanın CNV analizi gerçekleştirildi. CNV bulgularımızın analizi ve veritabanlarının taranması ile DAD1 geni CBAVD ile ilişkili olabilecek potansiyel aday gen olarak tanımlandı. 22 CBAVD'li hastada da DAD1 geni ekzonlarının dizi analizi Sanger dizileme metoduyla yapıldı.

Bulgular: 19 hastanın dokuzunda (\%47.3) hastalıkla ilişkili olabilecek 11 adet CNV saptandı. En sık saptanan CNV olarak 14q11.2 delesyonu, hastaların üçünde (\%15.79) belirlendi. 14q11.2 delesyonlarından ikisinin ortak varyant bölgesinde yalnızca DAD1 geni lokalize idi. Dizi analizi ile, hastaların DAD1 geninde herhangi bir dizi varyasyonu saptanmadı.

Sonuç: $14 q 11.2$ kromozomal bölgesi ve DAD1 geni CBAVD ile ilişkili olabilir. CNVlerin ve DAD1 geninin CBAVD etiyolojisine katkısını tanımlamak için ileri çalışmalar gerekmektedir.

Anahtar Kelimeler: kopya sayısı varyasyonları; CBAVD; erkek infertilitesi, DAD1

Received: 10.07.2021 Accepted: : 01.08.2021 Published (Online): 30.08.2021

*Coresponding Author: Durkadin Demir Eksi, Asst. Professor, Ph.D. Alanya Alaaddin Keykubat University,

Faculty of Medicine, Department of Medical Biology, Kestel Campus Alanya, Antalya, Turkey 07425.

Phone: +902425106060 / 3570 Fax: +902425106009 E-mail: durkadin.eksi@alanya.edu.tr.

ORCID: 0000-0002-5887-3141.

To cited: Demir Eksi D, Yilmaz E, Akin Y, Usta MF, Basar MM, Kahraman S, Erman M, Alper OM. Copy Number Variation Analysis in Turkish Patients with Congenital Bilateral Absence of Vas Deferens. Acta Med. Alanya 2021;5(2): 181-189 doi:10.30565/medalanya.966940 


\section{INTRODUCTION}

A $\mathrm{s}$ a global health problem, infertility affects approximately $8-12 \%$ of all couples [1]. It has been estimated that $40-50 \%$ of all infertility cases is due to 'male factor' infertility and affects about $7 \%$ of all men [1]. Congenital structural anomalies of the male genital tract are contributing factors in male infertility. Numerical or structural chromosomal abnormalities, $Y$ chromosome microdeletions, and Cystic Fibrosis Transmembrane Conductance Regulator (CFTR, NM_000492.3) gene mutations associated with congenital bilateral absence of vas deferens (CBAVD, OMIM 277180) are the most common genetic reasons of male infertility [2]. CBAVD accounts for $1-2 \%$ of all male infertility, which is a condition characterized by the blockade of the transportation of the spermatozoa from testicular or epididymal structures to the distal genital tract, resulting in azoospermia [3]. 88\% of Caucasian, $78 \%$ of Non-Caucasian patients with CBAVD carry at least one CFTR mutation [4]. However, CFTR mutations were found to be less common in Turkish CBAVD patients [5-7]. We previously reported that only $15.90 \%$ had CFTR mutations [7]. The lower frequency of CFTR mutations among Turkish CBAVD cases, as well as differential mutation profiles, demonstrated the impact of geographical and ethnic backgrounds on CBAVD etiology [5, 7]. Besides CFTR, ADGRG2 (Adhesion G protein-Coupled Receptor G2) gene variants were identified as a cause of CBAVD with a prevalence of $7.4 \%$ and $20 \%$ in French and Chinese cases, respectively [8,9]. Recently, it was shown that, heterozygous SLC9A3 deletions were found in $37.9 \%$ of the Taiwanese patients, and SCNN1B and CA12 genes regulating CFTR protein levels were found to be associated with CBAVD in some patients without CFTR mutations [10,11]. Nevertheless, these gene variations explain the disease in only a limited fraction of all CBAVD patients. The genetic structure of the present day Turkish people may not be similar with Europeans or Asians because of migrations from different geographical areas [12]. We hypothesized novel genes and/or genomic regions may be related to idiopathic CBAVD in Turkish people.

Genomic copy number variations (CNVs) can lead to disease by various molecular mechanisms including gene dosage effect, gene disruption, gene fusion, position effect and other effects on gene function [13]. To date, CNV analyses for idiopathic azoospermia from different ethnic backgrounds or populations have been performed in several studies $[14,15]$. We hypothesise that CNVs might explain, at least partially, the unknown genetic etiology of CBAVD. Therefore, we aimed to identify the possible candidate genomic regions and genes which could cause CBAVD in Turkish patients not carrying CFTR mutations by performing whole genome CNV analysis. Here, we report that Defender Against Cell Death 1 (DAD1) localized at $14 q 11.2$ in our cohort is a gene that may need to be investigated further in association with CBAVD. DAD1 is known to be a negative regulator of apoptosis [16].

\section{MATERIALS AND METHODS}

\section{Ethical approval and patients}

This clinico-genetic study was conducted with the collaboration of Akdeniz University Faculty of Medicine, Izmir Katip Celebi University Faculty of Medicine, and Istanbul Sisli Memorial Hospital, Turkey. The study protocol was approved by the Akdeniz University Clinical Research Ethics Committee (approval No: 2014-\# 383) under the recent version of the Helsinki Declaration. Informed consent was obtained from all subjects when they were enrolled in the study.

The patients who applied to the urology outpatient clinic due to primary infertility were evaluated. All of the patients had not used any birth control method for at least one year, they had no sexual dysfunction and no comorbidity. Twenty-two unrelated, adult Anatolia-originated Caucasian males with CBAVD were included in the study. All patients were azoospermic. CBAVD patients were determined by using physical examination, scrotal, transrectal ultrasound (USG), semen analysis, and biochemical tests. CBAVD cases with wildtype CFTR genotype, normal karyotype, without a $\mathrm{Y}$ chromosome microdeletion were included in this study. Renal aplasia was excluded by pelvic USG.

\section{Copy Number Variation Analysis}

For molecular genetic analyses, patients' genomic DNA was isolated from peripheral blood by using a non-enzymatic method modified from Lahiri and 
Nurnberger [17]. The quality of DNA samples was tested by agarose gel electrophoresis and by measuring the A260/A280 ratios on the Nanodrop 8000 Spectrophotometer (Thermoscientific Instruments, CA, USA). Nineteen DNA samples of sufficient quality for microarray were examined for whole-genome CNVs. Nine out of the 19 samples were profiled by using the Affymetrix CytoScan HD Array (Affymetrix, Santa Clara, CA, USA). Affymetrix CytoScan HD Array is a high-density platform containing more than 2.6 million-copy number markers with 750.000 SNP markers. Agilent ISCA 8x60K CGH Array (Agilent Technologies, Santa Clara, CA, USA), comprised of 60.000 oligonucleotide probes, was used for the rest of the samples. After the wet laboratory steps according to the manufacturer's instructions, data were analyzed and visualized with different software (Affymetrix Chromosome Analysis Suite 3.1, Agilent Cytogenomics 4.0.2.21.) depending on the platform utilized. In Affymetrix Chromosome Analysis Suite software to exclude false-positive $\mathrm{CNVs}$, only deletions and duplications more than $100 \mathrm{Kbp}$ in length that involved at least 25 and 50 consecutive probes respectively were considered real alterations. In Agilent Cytogenomics software at least $100 \mathrm{Kbp}$ of DNA amplification or deletions including a minimum of 4 consecutive probes were reported as real copy number variations. Human genome hg19 assembly was used to map genomic coordinates, and CNVs were classified as pathogenic, variants of uncertain significance, likely benign, and benign following the latest ACMG guidelines [18]. To determine the pathogenicity of detected CNV regions; DGV (http://projects.tcag. ca/cgi-bin/variation/gbrowse/hg19/), DECIPHER (https://decipher.sanger.ac.uk/), ClinVar (https:// www.ncbi.nlm.nih.gov/clinvar/) databases were used. We excluded benign CNVs that had previously been reported to occur in healthy individuals frequently and reported CNVs possibly associated with a pathology.

Selection of the possible candidate gene for CBAVD

Overlapping CNV regions in at least two patients were determined by comparing the length of the shared sequence. The protein-coding gene/genes localized in the overlapping genomic region were hypothesized to be the potential candidate gene for CBAVD. The gene with a possible role in the development of the male genital tract was selected through a review of the literature (https://www. ncbi.nlm.nih.gov/pubmed) as well as databases on gene expression profiles (http://www.proteinatlas. org/), genotype-phenotype correlations (http:// omim.org/, https://www.ncbi.nlm.nih.gov/gene), and animal models (http://www.informatics.jax. org/).

\section{Sanger DNA sequencing for $D A D 1$}

Defender Against Cell Death 1 (DAD1) (NM_001344.4) was found to be a potential candidate gene associated with CBAVD by this study because of its localization in the overlapping genomic region of the common CNVs. Sanger sequencing was performed in all $22 \mathrm{CBAVD}$ patients for all three exons and exon-intron boundaries of DAD1. The polymerase chain reaction (PCR) oligonucleotide primer sets are shown in Table 1. Amplification conditions consisted of an initial denaturation at $95{ }^{\circ} \mathrm{C}$ for 8 minutes, followed by 35 cycles at $95^{\circ} \mathrm{C}$ for 30 seconds, $55^{\circ} \mathrm{C}$ for 30 seconds, $72{ }^{\circ} \mathrm{C}$ for 30 seconds, and a final extension at 72 ${ }^{\circ} \mathrm{C}$ for 5 minutes. Each fragment was resolved by agarose gel electrophoresis. Aliquots of the samples were subjected to dideoxy sequencing on an $A B I$ 3130XL Automated DNA Sequencer (Applied Biosystems, Foster City, CA, USA). NCBI Blast (http://blast.ncbi.nlm.nih.gov/Blast.cgi) was used to analyze obtained sequences.

Table 1: Primers used in Sanger sequencing of $D A D 1$

\begin{tabular}{|l|l|l|l|l|}
\hline Exon & $\begin{array}{l}\text { Forward primer } \\
\left(5^{\prime}->3^{\prime}\right)\end{array}$ & $\begin{array}{l}\text { Reverse primer } \\
\left(5^{\prime}->3^{\prime}\right)\end{array}$ & $\begin{array}{l}\mathrm{MgCl}_{2} \\
(\mathrm{mM})\end{array}$ & $\begin{array}{l}\mathrm{Tm} \\
{ }^{\circ} \mathrm{C}\end{array}$ \\
\hline 1 & $\begin{array}{l}\text { GGCGGTGGT- } \\
\text { CTGATATAGAGT }\end{array}$ & $\begin{array}{l}\text { AGCTCATTG- } \\
\text { ATAGGGCCATT }\end{array}$ & 1,4 & 55 \\
\hline 2 & $\begin{array}{l}\text { CCAGTCCCAT- } \\
\text { CCAATTTCTC }\end{array}$ & $\begin{array}{l}\text { TTTGGGGC- } \\
\text { TATCTGGGTATC }\end{array}$ & 1,4 & 55 \\
\hline 3 & $\begin{array}{l}\text { ACAAGGAGG- } \\
\text { CAGGTTCACAG }\end{array}$ & $\begin{array}{l}\text { GATTTGGGG- } \\
\text { CCCTGTCTCTA }\end{array}$ & 1,7 & 55 \\
\hline
\end{tabular}

\section{RESULTS}

Patients and clinical findings

The mean age of patients was $43 \pm 12$ years. All of the patients were primary infertile and azoospermic. On physical examination, the vas deferens of the patients were not palpable (both sides), and unilateral agenesis of vas deferens was confirmed radiologically. Their testicular volume 
Table 2: CNV profiles of Turkish CBAVD cases

\begin{tabular}{|c|c|c|c|c|c|c|c|c|c|c|}
\hline $\begin{array}{l}\text { Case } \\
\text { ID }\end{array}$ & $\begin{array}{l}\text { CNV } \\
\text { Type }\end{array}$ & Chr. Region & $\begin{array}{l}\text { Coordinates } \\
\text { (hg19) }\end{array}$ & $\begin{array}{l}\text { Gain/ } \\
\text { Loss }\end{array}$ & $\begin{array}{l}\text { Size } \\
(\mathrm{Kbp})\end{array}$ & $\begin{array}{l}\text { Gene } \\
\text { Quantity }\end{array}$ & Gene Involved & $\begin{array}{l}\text { \# times in } \\
\text { DGV }\end{array}$ & $\begin{array}{l}\text { \# times in } \\
\text { Decipher }\end{array}$ & Microarray \\
\hline 8 & $\mathrm{P}$ & $\begin{array}{l}15 q 13.2 \\
q 13.3\end{array}$ & $\begin{array}{l}\text { chr15:30,954,76- } \\
32,509,926\end{array}$ & Loss & 1555 & 7 & $\begin{array}{l}\text { FAN1, MTMR10, } \\
\text { TRPM1, MIR211, } \\
\text { KLF13, OTUD7A, } \\
\text { CHRNA7 }\end{array}$ & $\begin{array}{l}1 \\
\text { (Multiple) }\end{array}$ & $1(0)$ & $\begin{array}{l}\text { Agilent } \\
\text { ISCA } \\
8 \times 60 \mathrm{~K}\end{array}$ \\
\hline 4 & VUS & $11 \mathrm{q} 14.3$ & $\begin{array}{l}\text { chr11:89,474,817- } \\
89,895,988\end{array}$ & Gain & 421 & 10 & $\begin{array}{l}\text { TRIM49, MIR5692A1, } \\
\text { TRIM53AP, TRIM64B, } \\
\text { TRIM49D2P, } \\
\text { TRIM49D1, TRIM64, } \\
\text { TRIM49C, UBTFL1, } \\
\text { NAALAD2 }\end{array}$ & $\begin{array}{l}4 \\
\text { (Multiple) }\end{array}$ & $0(0)$ & $\begin{array}{l}\text { Affymetrix } \\
\text { CytoScan } \\
\text { HD }\end{array}$ \\
\hline 18 & VUS & $14 \mathrm{q} 11.2$ & $\begin{array}{l}\text { chr14:22,215,286- } \\
24,018,428\end{array}$ & Loss & 1803 & $>30$ & $\begin{array}{l}\text { DAD1, ABHD4, OXA1L, } \\
\text { SLC7A7, MRPL52, } \\
\text { MMP14, LRP10, REM2, } \\
\text { RBM23, PRMT5, } \\
\text { HAUS4, JUB, C14orf93, } \\
\text { PSMB5, PSMB11, } \\
\text { CDH24, ACIN1, } \\
\text { 14orf119,CEBPE, } \\
\text { SLC7A8... }\end{array}$ & $\begin{array}{l}0 \\
\text { (Multiple) }\end{array}$ & $0(0)$ & $\begin{array}{l}\text { Agilent } \\
\text { ISCA } \\
8 \times 60 \mathrm{~K}\end{array}$ \\
\hline 19 & VUS & $14 q 11.2$ & $\begin{array}{l}\text { chr14:22,299,149- } \\
23,061,615\end{array}$ & Loss & 762 & 1 & $D A D 1$ & $\begin{array}{l}7 \\
\text { (Multiple) }\end{array}$ & $0(0)$ & $\begin{array}{l}\text { Agilent } \\
\text { ISCA } \\
8 \times 60 \mathrm{~K}\end{array}$ \\
\hline 8 & VUS & $15 q 13.3-q 14$ & $\begin{array}{l}\text { chr15:32,942,601- } \\
34,627,075\end{array}$ & Gain & 1684 & 11 & $\begin{array}{l}\text { SCG5, GREM1, FMN1, } \\
\text { RYR3, AVEN, CHRM5, } \\
\text { C15orf24, PGBD4, } \\
\text { C15orf29, TMEM85, } \\
\text { SLC12A6 }\end{array}$ & $\begin{array}{l}4 \\
\text { (Multiple) }\end{array}$ & $0(0)$ & $\begin{array}{l}\text { Agilent } \\
\text { ISCA } \\
8 \times 60 \mathrm{~K}\end{array}$ \\
\hline 15 & VUS & $17 \mathrm{p} 13.3$ & $\begin{array}{l}\text { chr17:625,416- } \\
810,197\end{array}$ & Gain & 185 & 5 & $\begin{array}{l}\text { FAM57A, GEMIN4, } \\
\text { DBIL5P, GLOD4, } \\
\text { RNMTL1, NXN }\end{array}$ & $\begin{array}{l}13 \\
\text { (Multiple) }\end{array}$ & $0(0)$ & $\begin{array}{l}\text { Agilent } \\
\text { ISCA } \\
8 \times 60 \mathrm{~K} \\
\end{array}$ \\
\hline 9 & VUS & 18p11.21 & $\begin{array}{l}\text { chr18:14,194,813- } \\
14,851,736\end{array}$ & Gain & 657 & 6 & $\begin{array}{l}\text { ANKRD20A5, } \\
\text { CYP4F35P, } \\
\text { CXADRP3, POTEC, } \\
\text { ANKRD30B, MIR3156- } \\
2\end{array}$ & $\begin{array}{l}2 \\
\text { (Multiple) }\end{array}$ & $0(0)$ & $\begin{array}{l}\text { Affymetrix } \\
\text { CytoScan } \\
\text { HD }\end{array}$ \\
\hline 4 & VUS & $\mathrm{Xp}_{\mathrm{p} 22.33}$ & $\begin{array}{l}\text { chrX:795,717- } \\
1,427,556\end{array}$ & Gain & 632 & 3 & $\begin{array}{l}\text { CRLF2, CSF2RA, } \\
\text { MIR3690 }\end{array}$ & $\begin{array}{l}3 \\
\text { (Multiple) }\end{array}$ & $0(1)$ & $\begin{array}{l}\text { Agilent } \\
\text { ISCA } \\
8 \times 60 \mathrm{~K}\end{array}$ \\
\hline 6 & VUS & Yq11.223 & $\begin{array}{l}\operatorname{chrY:25,296,950-} \\
26,066,972\end{array}$ & Gain & 770 & 2 & $D A Z 1, D A Z 2$ & $3(66)$ & $0(3)$ & $\begin{array}{l}\text { Agilent } \\
\text { ISCA } \\
8 \times 60 \mathrm{~K} \\
\end{array}$ \\
\hline 1 & LB & $2 \mathrm{q} 21.2$ & $\begin{array}{l}\text { chr2:132,696,181- } \\
133,136,747\end{array}$ & Gain & 441 & 2 & $\begin{array}{l}A N K R D 30 B L, \\
M I R 663 B\end{array}$ & $\begin{array}{l}13 \\
\text { (Multiple) }\end{array}$ & $0(0)$ & $\begin{array}{l}\text { Affymetrix } \\
\text { CytoScan } \\
\text { HD }\end{array}$ \\
\hline 7 & B & $14 \mathrm{q} 11.2$ & $\begin{array}{l}\text { chr14:22,598,026- } \\
22,897,089\end{array}$ & Loss & 299 & 0 & - & $\begin{array}{l}26 \\
\text { (Multiple) }\end{array}$ & $0(0)$ & $\begin{array}{l}\text { Agilent } \\
\text { ISCA } \\
8 \times 60 \mathrm{~K}\end{array}$ \\
\hline
\end{tabular}

Abbreviations: P, pathogenic; VUS, variant of uncertain clinical significance; LB, likely benign; B, benign; Chr, Chromosome; Kbp, kilobase pair; DGV, Database of Genomic Variants. The number of CNVs in a very similar size is listed for both DGV and Decipher. The number of any size of CNVs overlapped any part of our $\mathrm{CNV}$ region is shown in parentheses. 
and penises were normal. However all patients are infertile and azoospermic, their ejaculate volumes, semen glucosidase and/or fructose levels and blood follicle stimulating hormone (FSH) levels $(1.7-12 \mathrm{mlU} / \mathrm{ml})$ were normal. In addition, transrectal ultrasound (TRUS) demonstrated no other obstructive cause for azoospermia. There was no other abnormality accompanying CBAVD.

\section{Genomic Copy Number Variations}

In nine of the 19 patients (47.3\%), we detected CNVs including a pathogenic $(P)$ deletion, a likely benign (LB) variant of duplication and eight variants of uncertain significance (VUS) consisting of two deletions and six duplications. A benign (B) deletion $(299 \mathrm{Kbp})$ in the $14 q 11.2$ region containing no known genes was also detected in a different patient. We reported this benign variation as an exceptional due to its localization in a recurrent $\mathrm{CNV}$ region. The types and localization of these $\mathrm{CNVs}$, minimum-maximum nucleotide numbers that show the borders in chromosomal DNA (based on hg19), length in base pairs, number of genes included in that region were listed in Table 2. All CNVs were detected in a heterozygous state. The average size of the CNVs was $837 \mathrm{Kbp}$. Duplications were more common than deletions (64\% versus $36 \%)$.

In Case 8, we identified two CNVs, a pathogenic and a VUS on chromosome 15. Each of the other CNVs was found in different patients. The 15q13.2-q13.3 deletion in Case 8 was defined as pathogenic according to the ACMG criteria. This deletion was $1555 \mathrm{Kbp}$ in length, for which a similar sized CNV present once in both DGV and DECIPHER CNV Syndromes. It overlapped with the genomic region associated with $15 q 13.3$ microdeletion syndrome. Within the $15 q 13.2-q 13.3$ deletion, there were seven protein-coding genes (Table 2). We have had no data on whether the case 8 having the the clinical features of $15 q 13.3$ microdeletion syndrome. There was no any other similar sized CNV present in DECIPHER for the other CNVs. When any sized CNV that overlaps our CNVs is considered, this was seen multiple times in DGV for most of all (66 times for the Yq11.223 duplication) and none in DECIPHER except the duplications of Xp22.33 (once) and Yq11.223 (three times) (Table 2).
Possible candidate gene and direct sequencing

As shown in the Table 2, deletions in the $14 q 11.2$ chromosomal region was detected in $15.79 \%$ $(n=3)$ of 19 patients. Software images of the 14q11.2 deletions are shown in Figures 1A, 1B and $1 \mathrm{C}$. The overlapping genomic region of these three was $299 \mathrm{Kbp}$ length where no known protein coding genes were localised. On the other hand, DAD1 was the only gene localised in the overlapped region of two of the $14 q 11.2$ deletions (Figure 2). DAD1 is a core subunit of the oligosaccharyltransferase (OST) complex catalyzes $\mathrm{N}$-glycosylation of target proteins which is a key modification occurring in eukaryotes. Lossof-function of the DAD1 protein triggers apoptosis [19]. Homozygous Dad1 knockout mice models are embryonically lethal revealing essential role of the gene in embryological development [20]. DAD1 protein is expressed as medium level in male reproductive system tissues (https:// www.proteinatlas.org/ENSG00000129562DAD1/tissue). N-glycosylation, a common cotranslational modification, is the attachment of the core oligosaccharide to the asparagine residue of a protein by the OST. N-glycosylation defects cause impairments in the folding and stability of CFTR protein [21]. DAD1 is one of the globular modulators of OST stability thus affects directly OST dependent N-glycosylation [19]. Based on these results, $D A D 1$ gene coding a protein functioning in the posttranslational modification process of CFTR may lead to CBAVD in cases without CFTR mutations. Sequence analysis was performed to investigate if DAD1 (NM_001344.4) single nucleotide variations contribute to CBAVD etiology. No variation was detected by Sanger sequencing of $D A D 1$ in our cohort of the study group.

\section{DISCUSSION}

If any potentially pathogenic CNV is common in a cohort with a specific phenotype, that CNV region can be thought of as a candidate region for that physiological condition [22]. Within the scope of this study, we aimed to identify the most likely pathogenic CNVs that can cause a CBAVD phenotype. Genetic studies on etiology of CBAVD in Turkish population are very limited. This is the first study investigating CNVs and candidate 

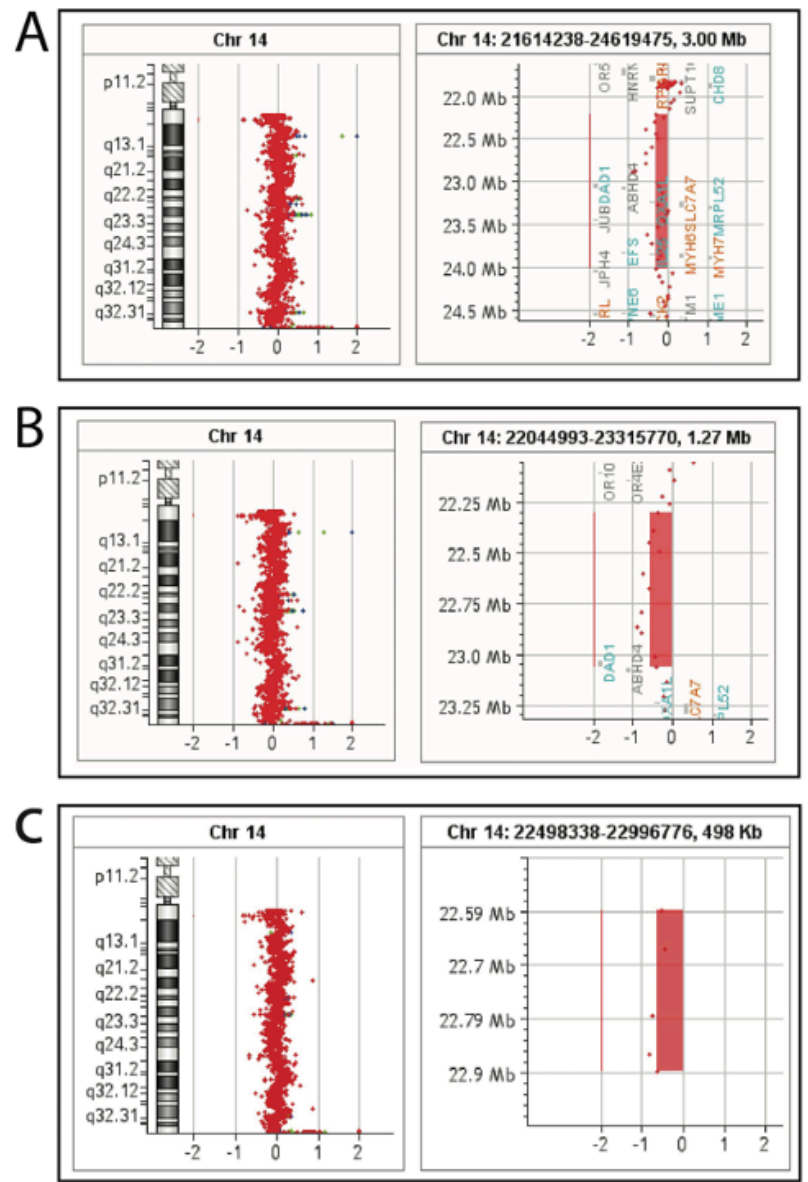

Figure 1: CNV analysis results of heterozygous 14q11.2 deletions. A) $1803 \mathrm{Kbp}$ deleted region. B) $762 \mathrm{Kbp}$ deleted region. C) $299 \mathrm{Kbp}$ deleted region. The images show the $\log 2$ ratio of the reference versus patient DNA on the $\mathrm{Y}$-axis and the position of each probe along the chromosome on the $\mathrm{X}$-axis. Vertical red bars indicate the deleted genomic region. Images were produced using Agilent Cytogenomics 4.0.2.21 software.

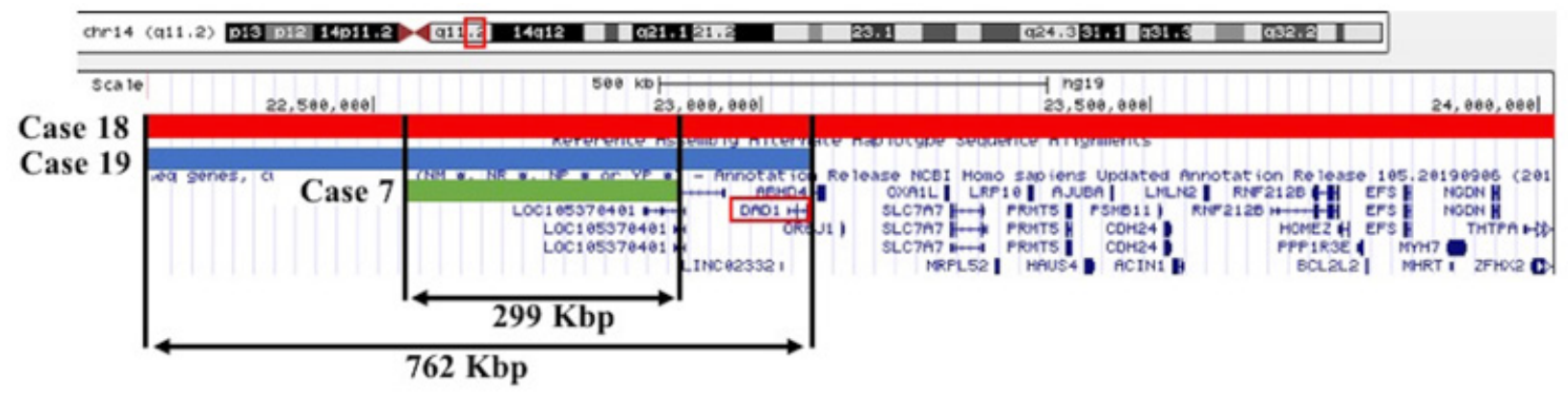

Figure 2: Identification of reciprocal overlap in size for 14q11.2 deletions. Each colored bar (red, blue, green) represents CNV calls in cases 18, 19, and 7 respectively. Three $\mathrm{CNV}$ calls each shares a genomic region of $299 \mathrm{Kbp}$ length at that locus. The overlapping region of two $\mathrm{CNV}$ calls is $762 \mathrm{Kbp}$ in length and harbours the DAD1 gene which is marked with a red colored rectangle.

genomic regions or genes associated with CBAVD in Turkish cases. We reported large CNVs by using high-resolution array technologies without any other confirmation from an alternative method in the light of our previous studies [23, 24].

We evaluated the clinical findings of CBAVD patients. Despite the ejaculate volume and the fructose levels are usually low in CBAVD men [25]; we detected normal levels of ejaculate volumes and seminal glucosidase and/or fructose concentrations in our study group as we reported before [7]. Lin et al. also reported a case with CBAVD having normal semen parameters [26]. 
Additionally, Van der Ven $\mathrm{K}$ et al. and reported that CFTR mutations were variable and that CFTR mutations may cause reduced sperm quality without non-obstructive azoospermia or low fructose volume [27, 28]. Wedenoja et al. agreed with them [28]. Thus, CFTR mutations are related to variable semen parameters that may range from normal to subnormal semen parameters. We excluded CBAVD patients having CFTR mutations. They had no additional genital abnormalities that were seen on TRUS imaging. Moreover, it has been shown that CBAVD patients with renal aplasia did not have CFTR mutations [29]. Besides, the absence of unilateral vas deferens may be part of renal malformations. Gajbhiye et al. published that CFTR mutations could be detected with renal malformations [30]. However, we ruled out renal aplasia by using radiological evaluations, and we have not gotten any infertile patients with renal malformations. Nevertheless, we have one of the largest patient populations with CFTR mutations in our Turkish community and all genomic mutations were recorded.

The pathophysiology of CBAVD cannot be explained only by CFTR mutations, suggesting possible genetic heterogeneity. CNV studies to determine the underlying etiology of idiopathic CBAVD are very limited. To date, a study was done by Lee et al. investigating CNVs by using array $\mathrm{CGH}$ in Taiwanese CBAVD patients $(n=8)$ in 2009. The researchers identified CNVs in the 3 q26 chromosomal region in five of their cases and proposed that this region can be related to CBAVD. In addition, they also detected CNVs in a region including the PANK2 gene that plays a role in the development of the urinary system in two of their cases. In our cohort, no CNV was detected in neither the 3q26 nor in the 20p12 region containing the PANK2 gene. CNVs were found in the $Y q 11.223$ region by both of the studies. While they detected a deletion in the Yq11.223, we determined an amplification [3]. The very low number of CNVs shared between our patients and Taiwanese patients may be due to ethnic and geographic differences between populations.

Despite the presence of apparently benign CNVs in the human genome, a large number of CNVs are involved in the etiology of various human diseases. Therefore, CNVs are an important source of mutation burden associated with human diseases. The disease phenotype occurs depending on the functions of the genes in the CNV region [22]. We searched the literature in terms of the possible relationship of genes localized in our CNV regions with the male reproductive system. However, we could not find a gene known to be directly related to the development of the male reproductive system. CBAVD exhibited variable inheritance patterns like autosomal recessive, autosomal dominant, and X-linked [25]. We found all CNVs present in heterozygous state. The significance of the heterozygous CNVs in the pathogenesis of CBAVD is unknown but suggests a possible inheritance model of autosomal dominant.

The most noteworthy findings in our study are the 14q11.2 (762 Kbp, $1803 \mathrm{Kbp}, 299 \mathrm{Kbp}$ ) deletions in three of the cases. CNVs in the $14 q 11.2$ region have also been identified in infertile men in other studies. Tüttelmann et al. performed CNV analysis in Caucasian patients with idiopathic severe oligozoospermia and Sertoli-cell-only syndrome (SCOS). They determined 14q11.2 deletions and duplications both in their patient and normozoospermic control group. All were 222.3 $\mathrm{Kbp}$ length and did not overlap with the ones we detected. In addition, the Yq11.223 duplication that they found in SCOS patients was also detected in our patient group [31]. Halder et al. revealed CNVs in Indian patients with testicular maturation arrest. They also found CNVs (smallest: 207 $\mathrm{Kbp}$, largest: $\sim 219 \mathrm{Kbp}$ ) in the $14 \mathrm{q} 11.2$ region as gain or loss in 10 patients. These CNVs did not overlap with ours, they were located in the upstream region of the $14 q 11.2 \mathrm{del}$ segments we identified [32]. CNVs in Australian cases with azoospermia were investigated in another study. The researchers found heterozygous duplications as pathogenic CNVs in chromosomes 3 and 11 containing various genes that may be associated with male infertility. Incompatible with our findings, they detected a 14q11.2 deletion ( $37 \mathrm{Kbp})$ in a case. This deletion overlapped with the $14 q 11.2$ deletions of ours but it was smaller in length, did not contain any gene, thereby considering benign. It was located downstream of the DAD1 gene [14]. In 2015, Dong et al. reported that three of 33 azoospermia cases had heterozygous CNVs in the 14q11.2 chromosomal region [15]. There was no overlapping region with the CNVs found 
in this study and they were located about 2.62.7 $\mathrm{Mb}$ downstream of the DAD1 gene. These results from different groups suggest the potential effects of $14 q 11.2$ in male infertility. The $14 q 11.2$ region was also associated with developmental delay, cognitive impairment, and similar minor anomalies [33]. In addition, it should be kept in mind that chromosome 14 has imprinted regions. Disruptions of the 14q11-q13 region may cause low birth weight and delayed growth, according to Kamnasaran and Cox [34]. Additionally, we detected $14 \mathrm{q} 11.2$ deletions containing the DAD1 in two of the cases (Case 18 and Case19). The 14q11.2 deletion in Case 7 was spanning 136.7 Kbp downstream of the DAD1 gene which coded on the minus strand of DNA. We can not exclude the regulatory role of this region on the $D A D 1$ gene, it should be further investigated. DAD1 is expressed both at mRNA and protein levels in the male genital tract. Rockett et al. has published that mRNA levels of the Dad1 gene can be decreased as a result of heat exposure in a heat-shocked testis mice model [35]. In addition, $D A D 1$ transcript is found to be down-regulated both in normozoospermic and asthenozoospermic groups when compared with the control group in a sperm transcriptome profiling study. As a result of these findings, it has been offered that apoptotic genes may play an important role in male infertility [36]. Although DAD1 is identified as an antiapoptotic molecule that regulates programmed cell death negatively, it is one of the subunits of oligosaccharyltransferase (OST) that catalyzes the protein $\mathrm{N}$-glycosylation process in eukaryotes [16, 19]. It has been thought that, as a common posttranslational modification, $\mathrm{N}$-glycosylation affects plasma membrane expression of glycoproteins by organizing the folding, targeting, and transportation through the endoplasmic reticulum (ER) [21]. It has been stated, that as a result of Glozman et al.'s study, N-glycans enhanced CFTR folding efficiency and the limited folding efficiency (30$40 \%$ ) of the wild type CFTR in the ER, conceivably reflect inefficient posttranslational domain assembly [21]. Thus, it has been mentioned that an $\mathrm{N}$-glycosylation defect reduces the cell surface expression of CFTR. According to $\mathrm{Li}$ et al., for the sperm capacitation, acrosome reaction, and sperm-oocyte fusion, wild-type CFTR protein is a necessity, and deficient CFTR protein expression may affect the sperm fertilizing capacity [37]. When we consider the relationship between CFTR and CBAVD as a part of OST, defects in the $D A D 1$ gene may cause an insufficient CFTR via the $\mathrm{N}$-glycosylation process which may result in the CBAVD phenotype. As stated by Flannigan and Schlegel in 2017, there is an urgent need for specific genomic biomarkers in the diagnosis of CBAVD [38].

Limitation of Study: This study was a pilot study aimed to identify novel potential candidate genomic regions and/or genes related to CBAVD. Number of patients included to the study were relatively low. CNV analysis should be done in larger cohorts of CBAVD patients to identfy the candiate genomic regions first, and then the alternative biologic mechanisms associated with the disease pathophysiology.

\section{Conclusion}

Our study was the first study profiling CNVs in Turkish-Caucasian patients with CBAVD. The spectrum and frequency of nuclear gene mutations and copy number variations in Turkish patients with CBAVD are still largely unknown. These patients underscore the importance of comprehensive genomic analysis in TurkishCaucasian patients. Using additional technologies and functional analyses will help us understand the mechanism of the disease and will highlight the interactions between phenotypes and genotypes. In the light of our data, we suggest that CNV and DAD1 analysis should be done in a larger cohort of CBAVD patients to determine potential chromosomal regions and genes for CBAVD cases related to male infertility.

Conflict of Interest: The author has no conflict of interest related to this article.

Funding sources: This study was supported by the Scientific and Technological Research Council of Turkey, TUBITAK, SBAG under Grant number $115 S 171$.

Ethics Committee Approval:Akdeniz University Clinical Research EthicsCommittee (No: 2014-\# 383)

Peer-review: Externally and internally peer reviewed.

Acknowledgements: We are thankful to the 
patients who participated in the study. We also thank Dr. Lynn P. Chorich for checking the spelling.

\section{REFERENCES}

1. Kumar N, Singh AK. Trends of male factor infertility, an important cause of infertility: A review of literature. J Hum Reprod Sci. 2015;8(4):191-6. doi: 10.4103/09741208.170370

2. Lidegaard O, Mikkelsen AL, Meldgaard M, Brondum-Nielsen K, Lindenberg S. Severe male infertility. Impact of genetic factors on diagnosis and counselling. Acta Obstet Gynecol Scand. 1998;77(8):799-803. PMID: 9776591.

3. Lee $\mathrm{CH}$, Wu CC, Wu YN, Chiang HS. Gene copy number variations in Asian patients with congenital bilateral absence of the vas deferens. Human reproduction 2009;24(3):748-55. doi: 10.1093/humrep/den413.

4. Yu J, Chen Z, Ni Y, Li Z. CFTR mutations in men with congenital bilateral absence of the vas deferens (CBAVD): a systemic review and meta-analysis. Human reproduction. 2012;27(1):25-35. doi: 10.1093/humrep/der377

5. Ocak Z, Uyetuork U, Dincer MM. Clinical and prognostic importance of chromosomal abnormalities, $Y$ chromosome microdeletions, and CFTR gene mutations in individuals with azoospermia or severe oligospermia. Turk J Med Sci. 2014;44(2):347-51. PMID: 25536748.

6. Dayangac D, Erdem H, Yilmaz E, Sahin A, Sohn C, Ozguc M, et al. Mutations of the CFTR gene in Turkish patients with congenital bilateral absence of the vas deferens. Human reproduction. 2004;19(5):1094-100. doi: 10.1093/humrep/deh223.

7. Akin Y, Demir D, Gorgisen G, Luleci G, Alper OM, Watanabe CS, et al. Novel and rare CFTR gene mutations in Turkish patients with congenital aplasia of vas deferens. Andrologia. 2014;46(2):198-9. doi: 10.1111/and.12053.

8. Patat O, Pagin A, Siegfried A, Mitchell V, Chassaing N, Faguer S, et al. Truncating Mutations in the Adhesion G Protein-Coupled Receptor G2 Gene ADGRG2 Cause an X-Linked Congenital Bilateral Absence of Vas Deferens. Am J Hum Genet. 2016;99(2):437-42. doi: 10.1016/j.ajhg.2016.06.012.

9. Yang B, Wang J, Zhang W, Pan H, Li T, Liu B, et al. Pathogenic role of ADGRG2 in CBAVD patients replicated in Chinese population. Andrology. 2017:5(5):954-7. in CBAVD patients replic $10.1111 /$ andr. 12407 .

10. Shen Y, Yue HX, Li FP, Hu FY, Li XL, Wan Q, et al. SCNN1B and CA12 play vital roles in occurrence of congenital bilateral absence of vas deferens (CBAVD). Asian J Androl. 2019. doi: 10.4103/aja.aja_112_18.

11. Wu YN, Chen KC, Wu CC, Lin YH, Chiang HS. SLC9A3 Affects Vas Deferens Development and Associates with Taiwanese Congenital Bilateral Absence of the Vas Deferens. BioMed research international. 2019;2019:3562719. doi: $10.1155 / 2019 / 3562719$.

12. Hodoglugil U, Mahley RW. Turkish population structure and genetic ancestry revea relatedness among Eurasian populations. Ann Hum Genet. 2012;76(2):128-41. doi: 10.1111/.j.1469-1809.2011.00701.x

13. Zhang F, Gu W, Hurles ME, Lupski JR. Copy number variation in human health disease, and evolution. Annu Rev Genomics Hum Genet. 2009;10:451-81. doi: 10.1146/annurev.genom.9.081307.164217.

14. Eggers S, DeBoer KD, van den Bergen J, Gordon L, White SJ, Jamsai D, et al. Copy number variation associated with meiotic arrest in idiopathic male infertility. Fertility and sterility. 2015;103(1):214-9. doi: 10.1016/j.fertnstert.2014.09.030.

15. Dong $Y$, Pan $Y$, Wang R, Zhang Z, Xi Q, Liu RZ. Copy number variations in spermatogenic failure patients with chromosomal abnormalities and unexplained azoospermia. Genet Mol Res. 2015;14(4):16041-9. doi: 10.4238/2015.December.7.17.

16. Makishima $T$, Nakashima T, Nagata-Kuno K, Fukushima K, lida H, Sakaguchi $\mathrm{M}$, et al. The highly conserved DAD1 protein involved in apoptosis is required for N-linked glycosylation. Genes Cells. 1997;2(2):129-41. doi: 10.1046/j.1365 2443.1997.1070303.x.

17. Lahiri DK, Nurnberger JI, Jr. A rapid non-enzymatic method for the preparation of HMW DNA from blood for RFLP studies. Nucleic Acids Res. 1991;19(19):5444. doi: 10.1093/nar/19.19.5444

18. Riggs ER, Andersen EF, Cherry AM, Kantarci S, Kearney H, Patel A, et al. Technical standards for the interpretation and reporting of constitutional copy-number variants: a joint consensus recommendation of the American College of Medical Genetics and Genomics (ACMG) and the Clinical Genome Resource (ClinGen) Genet Med. 2020;22(2):245-57. doi: 10.1038/s41436-019-0686-8.

19. Roboti P. High S. The oligosaccharyltransferase subunits OST48, DAD1 and KCP2 function as ubiquitous and selective modulators of mammalian $\mathrm{N}$-glycosylation. $J$ Cell Sci. 2012;125(Pt 14):3474-84. doi: 10.1242/jcs. 103952.

20. Brewster JL, Martin SL, Toms J, Goss D, Wang K, Zachrone K, et al. Deletion of Dad1 in mice induces an apoptosis-associated embryonic death. Genesis. 2000;26(4):271-8

21. Glozman R, Okiyoneda T, Mulvihill CM, Rini JM, Barriere H, Lukacs GL. N-glycans are direct determinants of CFTR folding and stability in secretory and endocytic membrane traffic. J Cell Biol. 2009;184(6):847-62. doi: 10.1083/jcb.200808124.

22. Shaikh TH. Copy Number Variation Disorders. Curr Genet Med Rep. 2017;5(4):18390. doi: 10.1007/s40142-017-0129-2.

23. Demir Eksi D, Shen Y, Erman M, Chorich LP, Sullivan ME, Bilekdemir M, et al. Copy number variation and regions of homozygosity analysis in patients with MULLERIAN aplasia. Mol Cytogenet. 2018;11:13. doi: 10.1186/s13039-018-0359-3.

24. Williams LS, Demir Eksi D, Shen Y, Lossie AC, Chorich LP, Sullivan ME, et al Genetic analysis of Mayer-Rokitansky-Kuster-Hauser syndrome in a large cohort of families. Fertility and sterility. 2017;108(1):145-51 e2. doi: 10.1016/j.fertnstert.2017.05.017.
25. Bieth E, Hamdi SM, Mieusset R. Genetics of the congenital absence of the vas deferens. Hum Genet. 2021;140(1):59-76. doi: 10.1007/s00439-020-02122-w.

26. Lin $\mathrm{CH}$, Huang TY. Congenital bilateral absence of the vas deferens (CBAVD) with bilaterally present seminal vesicles. Urol Case Rep. 2020;31:101131. doi: 10.1016/j.eucr.2020.101131.

27. van der Ven $\mathrm{K}$, Messer L, van der Ven $\mathrm{H}$, Jeyendran RS, Ober C. Cystic fibrosis mutation screening in healthy men with reduced sperm quality. Human reproduction. 1996;11(3):513-7. doi: 10.1093/humrep/11.3.513.

28. Wedenoja S, Khamaysi A, Shimshilashvili L, Anbtawe-Jomaa S, Elomaa O, Toppari $\mathrm{J}$, et al. A missense mutation in SLC26A3 is associated with human male subfertility and impaired activation of CFTR. Scientific reports. 2017;7(1):14208. doi: 10.1038/ s41598-017-14606-3.

29. Schwarzer JU, Schwarz M. Significance of CFTR gene mutations in patients with congenital aplasia of vas deferens with special regard to renal aplasia. Andrologia. 2012;44(5):305-7. doi: 10.1111/j.1439-0272.2012.01281.x.

30. Gajbhiye R, Kadam K, Khole A, Gaikwad A, Kadam S, Shah R, et al. Cystic fibrosis transmembrane conductance regulator (CFTR) gene abnormalities in Indian males with congenital bilateral absence of vas deferens \& renal anomalies. Indian J Med Res. 2016;143(5):616-23. doi: 10.4103/0971-5916.187110.

31. Tuttelmann F, Simoni M, Kliesch S, Ledig S, Dworniczak B, Wieacker P, et al. Copy number variants in patients with severe oligozoospermia and Sertoli-cell-only syndrome. PloS one. 2011;6(4):e19426. doi: 10.1371/journal.pone.0019426.

32. Halder A, Kumar P, Jain M, Iyer VK. Copy number variations in testicular maturation arrest. Andrology. 2017;5(3):460-72. doi: 10.1111/andr.12330.

33. Yasin H Gibson WT, Langlois S, Stowe RM, Tsang ES, Lee L, et al. A distinct neurodevelopmental syndrome with intellectual disability, autism spectrum disorder, characteristic facies, and macrocephaly is caused by defects in CHD8. J Hum Genet. 2019;64(4):271-80. doi: 10.1038/s10038-019-0561-0.

34. Kamnasaran D, Cox DW. Current status of human chromosome 14. Journal of medical genetics. 2002;39(2):81-90. doi: 10.1136/jmg.39.2.81.

35. Rockett JC, Mapp FL, Garges JB, Luft JC, Mori C, Dix DJ. Effects of hyperthermia on spermatogenesis, apoptosis, gene expression, and fertility in adult male mice. Biol Reprod. 2001;65(1):229-39. doi: 10.1095/biolreprod65.1.229.

36. Bansal SK, Gupta N, Sankhwar SN, Rajender S. Differential Genes Expression between Fertile and Infertile Spermatozoa Revealed by Transcriptome Analysis. PloS one. 2015;10(5):e0127007. doi: 10.1371/journal.pone.0127007.

37. Li CY, Jiang LY, Chen WY, Li K, Sheng HQ, Ni Y, et al. CFTR is essential for sperm fertilizing capacity and is correlated with sperm quality in humans. Human reproduction. 2010;25(2):317-27. doi: 10.1093/humrep/dep406.

38. Flannigan R, Schlegel PN. Genetic diagnostics of male infertility in clinical practice. Best Pract Res Clin Obstet Gynaecol. 2017;44:26-37. doi: 10.1016/j.bpobgyn.2017.05.002

\begin{tabular}{|l|l|}
\hline Author/ORCID & Authorship Contrubition \\
\hline $\begin{array}{l}\text { Durkadin Demir Eksi } \\
\text { 0000-0002-5887-3141 }\end{array}$ & $\begin{array}{l}\text { Research conception and design, Data acquisition, } \\
\text { Data analysis and interpretation, Drafting of the } \\
\text { manuscript, Critical revision of the manuscript, } \\
\text { Obtaining funding, Administrative, technical, or } \\
\text { material support, Approval of the final manuscript }\end{array}$ \\
\hline $\begin{array}{l}\text { Elanur Yilmaz } \\
0000-0001-7045-5068\end{array}$ & $\begin{array}{l}\text { Data analysis and interpretation, Drafting of the } \\
\text { manuscript, Approval of the final manuscript }\end{array}$ \\
\hline $\begin{array}{l}\text { Yigit Akin } \\
0000-0001-7627-3476\end{array}$ & $\begin{array}{l}\text { Data acquisition, Critical revision of the } \\
\text { manuscript, Administrative, technical, or material } \\
\text { support, Approval of the final manuscript }\end{array}$ \\
\hline $\begin{array}{l}\text { Mustafa Faruk Usta } \\
\text { 0000-0001-6402-3269 }\end{array}$ & $\begin{array}{l}\text { Data acquisition, Administrative, technical, or } \\
\text { material support, Approval of the final manuscript }\end{array}$ \\
\hline $\begin{array}{l}\text { Mehmet Murad Basar } \\
0000-0002-4732-1923\end{array}$ & $\begin{array}{l}\text { Data acquisition, Administrative, technical, or } \\
\text { material support, Approval of the final manuscript }\end{array}$ \\
\hline $\begin{array}{l}\text { Semra Kahraman } \\
0000-0002-2686-4240\end{array}$ & $\begin{array}{l}\text { Data acquisition, Administrative, technical, or } \\
\text { material support, Approval of the final manuscript }\end{array}$ \\
\hline $\begin{array}{l}\text { Munire Erman } \\
0000-0002-3856-3787\end{array}$ & $\begin{array}{l}\text { Data acquisition, Administrative, technical, or } \\
\text { material support, Approval of the final manuscript }\end{array}$ \\
\hline $\begin{array}{l}\text { Oata analysis and interpretation, Critical revision } \\
\text { of the manuscript, Supervision, Approval of the } \\
\text { final manuscript }\end{array}$ \\
\hline
\end{tabular}

